Management, Information and Power 


\section{Information Systems Series}

Series Editor: Professor I.O. Angell

Computer Security Within Organizations Adrian R. Warman

Developing Information Systems - Concepts, Issues and Practice Chrisanthi Avgerou and Tony Cornford

Effective Systems Design and Requirements Analysis The ETHICS Approach

Enid Mumford

General Systems Theory - An Introduction Lars Skyttner

Information in Action - Soft Systems Methodology Lynda Davies and Paul Ledington

Management, Information and Power

A narrative of the involved manager Lucas D. Introna

Management of Information Systems Security Gurpreet Dhillon

Ourselves and Computers - Difference in Minds and Machines Aart Bijl

Systems Design - Ethical Tools for Ethical Change Enid Mumford

Understanding Information - An Introduction Jonathan Liebenau and James Backhouse 


\title{
Management, Information and Power
}

\author{
A narrative of the \\ involved manager \\ Lucas D. Introna \\ Department of Information Systems \\ London School of Economics and Political Science
}


All rights reserved. No reproduction, copy or transmission of this publication may be made without written permission.

No paragraph of this publication may be reproduced, copied or transmitted save with written permission or in accordance with the provisions of the Copyright, Designs and Patents Act 1988, or under the terms of any licence permitting limited copying issued by the Copyright Licensing Agency, 90 Tottenham Court Road, London W1P 9HE.

Any person who does any unauthorized act in relation to this publication may be liable to criminal prosecution and civil claims for damages.

The author has asserted his rights to be identified as the author of this work in accordance with the Copyright, Designs and Patents Act 1988.

First published 1997 by MACMILLAN PRESS LTD

Houndmills, Basingstoke, Hampshire RG21 6XS and London Companies and representatives throughout the world

ISBN 978-0-333-69870-9 DOI 10.1007/978-1-349-14549-2

A catalogue record for this book is available from the British Library.

This book is printed on paper suitable for recycling and made from fully managed and sustained forest sources. 
Dedicated to my mother

with gratitude and fondness

The desire to know and the craving for explanations will never bring us to

thoughtful questioning. Invariably the desire to know is already the concealed arrogance of self-consciousness which relies on fabricated reason and its reasonableness. Wanting to know does not want to relinquish hope in the face of that which is worthy of thought

\section{Martin Heidegger}

It is of cardinal importance that one should abolish the true world. It is the great inspirer of doubt and devaluator in respect of the world we are: it has been our most dangerous attempt yet to assassinate life.

Friedrich Nietzsche 


\section{Contents}

Preface

Acknowledgements

viii

$\mathrm{xi}$

1 Introduction: why and how to think?

2 The manager: involved in-the-world

3 Information: as understanding

4 Management: and manus

5 Power: the network of force relations

6 Management information:

knowing, explaining and arguing

7 Implications: so what and what now?

Selected bibliography

Figure and table index

Index

203 


\section{Preface}

This book started more than a decade ago. While working as a systems analyst, trying to develop management information systems, I became aware of the difficulty of answering seemingly obvious questions such as: "What is management information?"; "How do managers actually use it in doing whatever they do?". The world of management theory seemed so obvious and clear cut. I remember distinctly how excited I was on completing my MBA and having this sense of now knowing it. I could analyze, articulate, describe, suggest, solve, and a lot more. Yet, my everyday work seemed messy, unanalyzable, unarticulatable, unsolvable, and so on. No matter how hard one tried to be the manager that the theory said one ought to be, these eloquent models seemed to crumble in the face of the everyday 'getting the job done'. Getting the job done seemed to make the ideal increasingly elusive. Not only this, most of the managers for whom I tried to develop management information systems, talked about this sense of elusiveness in getting 'it' all together. Buried in the concerns of getting the everyday job done, absorbed in pushing it through, the world seemed to resemble a brawl in the bar rather than a chess game.

My initial reaction was that there seems to be a need to expand, or alter, our understanding of the nature of the everyday world of the manager in the organization. The more I immersed myself in a diverse body of literature, the more it became clear to me that there was a particular world view that informed the majority of management thinking; a world view deeply rooted in the Enlightenment, especially in the Descartes dualism. At the centre of this world view seemed to be the idea of the thinking, rational, purposive manager. Looking back at this realization, it is now apparent to me that this phenomenon of a particular world view dominating the discourse in a particular field is clearly not unique to management thought. However, what is unique, in my opinion, is the degree to which this world view seems to dominate in spite of numerous challenges, and in spite of an extensive and sustained deconstruction of the Enlightenment project that forms its basis. Why is this so?

Is it the pervasive moral legitimacy that this idea of a thinking, rational, purposive manager has? Is it that the alternative of an 'unthinking', 'irrational', 'purposeless' manager is just too ghastly to contemplate? Would managers lose their good name if they were to 
acknowledge that they are not the skilful planners and decision makers which they are made out to be, and which they, from time to time, believe themselves to be. To acknowledge that they are rather skilful opportunists that mostly depend on gut feel, that collude, coerce, and do whatever is necessary to get-the-job-done. Would it be too dangerous to contemplate this possibility? Is the image of a thinking, rational and purposive manager more true because it is more virtuous? Surely this cannot be an argument as Nietzsche (1973, p.39) aptly points out:

No one is likely to consider a doctrine true merely because it makes happy or makes virtuous.... Happiness and virtue are no arguments.... Something might be true although harmful and dangerous in the highest degree; indeed, it could pertain to the very fundamental nature of existence that a complete knowledge of it would destroy one - so that the strength of a spirit could be measured by how much truth it could take, more clearly, to what degree it needed, it attenuated, veiled, sweetened, blunted, and falsified.

What is the alternative then? This book is an attempt rearticulate the idea of the manager; the manager in the world; not as the thinking, rational and purposive manager but as the involved manager. The manager that is always already in-the-world. The manager that cannot escape the messyness, the ambiguity, the play of force, in a world that cannot be unentangled. Everything is already caught up, and tied to a whole, that has no logical beginning, no obvious logic, no simply present solutions, or ways out. There is no striating it out, or shaking it out, once and for all. The straightening it out and the shaking it out will itself become caught up, tied to, in many unexpected ways - where untying at one end may be tying at a whole lot of other ends. This is a world of being-in, of gut feel and thinking on your feet - in this world success is defined by your ability to see the gaps, grasp the opportunities and translate them into possibilities. This is the world of the involved manager; this is the image I will seek to present. It is not a neat and eloquent story; it is not a prescriptive story; but hopefully it is a real story - and this is why it is worth telling.

Heidegger will help us think through what it means to be an involved manager in-the-world. We are not in the world in a way a table is in the world. We are involved in a world that is present even before we think of it, plan it, or decide it. Gadamer, Wittgenstein and Heidegger will help us think through how this involved manager understands the world and acts 
in this world already known. They will help us understand what it means to make sense of the world. They will show us that the involved manager understands the world and knows how to act in it even before thinking, even before reasoning, and deciding. It may even be that what we call deciding, are merely acts of reifying what was already known in doing in the world. Ashby will help us to argue that control based on representational knowing will always lead to a zero-sum game; that every layer of externally located control will have to be paid for with a loss of flexibility in the lower level. Varela will help us think through what it means to get the job done in-the-world where we have collapsed the Taylor dualism, the layers; when we reunite thinking and doing. Foucault and Glegg will help us think through the network of power relations that are always already present in understanding and doing in the world. We will see that power cannot be escaped; that it is always already present. Finally, we will see how these concepts of the involved manager, information as understanding, and power, provide us with a useful framework to think through what management information means in-the-world of the involved manager.

This book is not finished. It is a rough draft. However, it needs to get out now. I suspect that many of the ideas in this book will relate to things currently being said by others - if the ideas, arguments and remarks in this book do not bear 'a stamp which mark them as mine', I do not wish to lay any further claim to them. Let me conclude this preface with some thoughts from Wittgenstein. His concluding paragraphs in the preface of his Philosophical Investigations is a clear reflection of how I feel about this book: "I should not like my writing to spare other people the trouble of thinking. But, if possible, to stimulate someone to thoughts of their own. I should have liked to produce a good book. This has not come about, but the time is past in which I could improve it."

Lucas Introna

London, 1997 


\section{Acknowledgements}

I would like to acknowledge all who have aided me in writing this book, many more than listed below. I know that as time goes by others will be remembered, others who should be mentioned by name, and to them I apologise for not giving them the credit they so richly deserve.

There are many persons who contributed to the initial forming of the ideas in this book; Dewald Roode for his patience as an initial sounding board for many of the ideas in this book. Also the staff of the Philosophy Department at the University of Pretoria who endured my enquiries and who listened to my ideas, in particular, Pieter Du Toit, Alex Antonites and Marius Schoeman. I hope I have done justice to the thoughts of the great thinkers they have aided me to understand. Various persons read the initial draft manuscript and provided excellent comments, I want to particularly mention Edgar Whitley, Rodrigo Magalhaes and Julika Siemer. I believe it would also be appropriate to explicitly acknowledge the extensive review done by Matthew Jones from the University of Cambridge who acted as reviewer for Macmillan. His comments vastly improved the final product.

For his collaboration on Chapter 5 I would like to acknowledge Leiser Silva. His intellectual contribution to this important chapter significantly enhanced it. Writing does not come easily to me. For his excellent job of taking my twisted prose and turning it into readable and enjoyable English I want to acknowledge Mike Cushman. Mike not only edited the book but made many invaluable comments on structure, logic, and flow. His contribution to this book has been significant in style and content.

There are always those who support your ideas and believe in your work in spite of your doubts. They inspire by always being there for you as mentor, friend, listener, and supporter. In this capacity I want to acknowledge the contributions made by Henry Lederle, Dewald Roode, Nick Du Plooy, Edgar Whitley, Dick Boland, Heinz Klein, Duane Truex, Kalle Lyytinen and Ian Angell. It is their belief in me that sustained me in moments of grave doubt. In particular I want to acknowledge the support of Ian Angell for getting this book into print. Many colleagues and friends listened to my ideas and tolerated my moments of joy and despair. They are: my colleagues at the University of Pretoria, my colleagues at The London School of Economics and Political Science, my brother Lorenzo and my friend Danie Le Roux. 
Finally, I want to acknowledge the many sacrifices made by my family. My parents, brothers and sisters who always encouraged me. I sincerely thank my wife and friend Georgie, for her critique and encouragement. She listened, always with interest, to these ideas for many years, at appropriate and inappropriate times, whether she felt like it or not. In conclusion, I would like to thank Georgie and my children Thomas and Isabelle who had to experience my absence, in mind and body, in the many hours that went into this work.

Lucas Introna 